\title{
TINGKAT KESIAPAN MENGAJAR \\ MAHASISWA PRODI.PENDIDIKAN AKUNTANSI \\ FAKULTAS ILMU SOSIAL DAN EKONOMI UNIVERSITAS NEGERI YOGYAKARTA
}

\author{
Oleh \\ Siswanto ${ }^{1}$
}

\begin{abstract}
Abstrak
Penelitian ini bertujuan untuk mengetahui Tingkat Kesiapan Mengajar Mahasiswa Prodi. Pendidikan Akuntansi Fakultas Ilmu Sosial dan Ekonomi Universitas Negeri Yogyakarta dilihat dari (1)Membuka dan menutup Pelajaran; (2)Penguasaan dan Penyampaian Materi;(3)Melakukan Interaksi dan Skenario Pembelajaran;(4)PenguasaanBahasa,Penampilan dan Alokasi Waktu;(5) Keterampilan MengajarMahasiswa dari segi Melakukan Evaluasi. Subjek penelitian ini adalah Mahasiswa Prodi. Pendidikan Akuntasi tahun 2011 yang telah menempuh PPL I dan PPL II. Penelitian ini menggunakan pendekatan ex post facto, karena peneitian ini hanya mengungkapkan fakta saja yang telah terjadi tanpa ada manipulasi variabel atau menciptakan kondisi tertentu. Dilihat dari sifatnya penelitian termasuk penelitian kuantitatif. Metode pengumpulan data dengan menggunakan kuesioner tertutup .Data yang diperoleh di analisis dengan pendekatan diskriptif kuantitatif, analisis ini digunakan untuk memgambarkan Tingkat Penguasaan Kesiapan Mengajar Mahasiswa Prodi. Pendidikan Akuntansi cara mengambarkan dalam tabel kecenderungan dengan kriteria yang telah ditentukan.

Hasil penelitian menunjukkan Tingkat Keterampilan Dasar Mengajar Mahasiswa Prodi. Pendidikan Akuntansi Fakultas Ilmu Sosial dan Ekonomi Universitas Negeri Yogyakarta :(1)KesiapanMembuka Pelajaran adalah Cukup Siap; (2) KesiapanPenguasaan dan Penyampaian Materi adalah Siap; (3) Kesiapan Melakukan Interaksi dan Skenario Pembelajaran adalah Cukup iap;(4) KesiapanPenguasaan Bahasa, Penampilan dan Alokasi Waktu adalah Cukup Siap; (5)Kesiapan Melakukan Evaluasi adalah Cukup Siap.
\end{abstract}

Kata Kunci: Kesiapan, Keteranpilan Dasar Mengajar

\section{PENDAHULUAN}

Pendidikan merupakan sarana penting untuk mendapatkan Sumber Daya Manusia (SDM) yang berkualitas untuk menjamin kelangsungan hidup dan kemajuan suatu bangsa. Minimnya SDM yang berkualitas sangat dipengaruhi oleh berkembangnya pendidikan di Indonesia saat ini (A Ubaidillah,2002) Indonesian peningkatan SDM merupakan hal yang sangat mendesak untuk segera di realisasikan untuk dapat menghadapi era global. Peningkatan SDM tidak akan lepas dari bagaimana pendidikan yang diperoleh oleh SDM tersebut, semakin baik pendidikan yang diperoleh maka diharapkan SDM tersebut akan memiliki kompetensi yang dapat dihandalkan. Pendidikan tinggi merupakan pendidikan yang diharapkan dapat mencetak tenaga kerja yang profesional untuk dapat melayani keinginan

\footnotetext{
${ }^{1}$ Dosen Jurusan Pendidikan Akuntansi - Universitas Negeri Yogyakarta
} 
masyarakat untuk menciptakan tenaga kerja yang profesional.Perguruan tinggi diharapkan dapat mencetak sarjana-sarjana profesional yang nantinya menjadi tulang punggung bangsa untuk meneruskan estafet pembangunan di dunia pendidikan.

LPTK (Lembaga Pendidikan Tenaga Kependidikan) merupakan Perguruan tinggi yang menjadi tumpuan untuk menghasilkan tenaga-tenaga profesional dalam dunia pendidikan.Keberhasilan LPTK dalam hal ini adalah perguruan tinggi sangat menentukan mutu dari SMK untuk menghasilkan lulusan yang siap pakai. Banyaknya lulusan LPTK tidak menjamin baiknya kualitas yang dihasilkan, oleh karena itu sangat perlu dilakukan kajian yang mendalam untuk dapat meningkatkan kuantitas serta kualitas LPTK .Untuk dapat mencetak tenaga-tenaga profesional dalam dunia pendidikan LPTK tentunya membutuhkan kompetensi mahasiswa yang memiliki kemampuan memadai untuk didik menjadi tenaga profesional. Baik serta buruknya kualitas lulusan secara tidak langsung sangat dipengaruhi oleh input yang diperoleh LPTK. Kompetensi Mahasiswa lulusan perguruan tinggi merupakan faktor penentu yang pertama diharapkan LPTK untuk dapat menjalankan fungsinya.

Fakultas Ilmu Sosial dan Ekonomi (FISE) Universitas Negeri Yogyakarta merupakan salah satu LPTK penyedia tenaga keguruan yang akan dimanfaatkan untuk menyediakan tenaga pendidik ditingkat Sekolah Mengengah Atas. Secara tidak langsung Fakultas Ilmu Sosial dan Ekonomi Universitas Negeri Yogyakarta memiliki andil yang besar dalam rangka menyediakan tenaga kerja tingkat menengah yang handal dengan penyediaan tenaga pendidik yang profesional. Keberhasilan FISE untuk menghasilkan tenaga yang profesional juga tergantung pada prestasi belajar mahasiswa dalam proses pembelajaran. Dalam proses perkuliahan telah memiliki pedomam pelaksanaan mengenai berbagai kompetensi yang harus dimiliki untuk menjadi seorang Pendidik yang tersusun dalam kurikulum setiap Program studi yang ditempuh mahasiswa.

Salah satu Program Studi yang mempersiapkan calon tenaga Guru adalah Prodi. Pendidikan Akuntansi. Prodi Pendidikan Akuntansi merupakan program pendidikan yang terfokus pada pembekalan berbagai kesiapan yang harus dimiliki oleh mahasiswa untuk menjadi seorang guru. Kurikulum pada Prodi Pendidikan Akuntansi telah disesuaikan dengan rambu-rambu pendidikan yang memberikan pemahaman dan kesiapan tentang kesiapan mengajar dan penyusunan administrasi pembelajaran, hal ini diharapkan dapat membekali mahasiswa nantinya setelah selesai studi untuk menjadi lulusan yang siap mengajar. Sarana dan Prasarana pendukung kegiatan Pembelajaran telah di sediakan untuk melaksanakan kurikulum tersebut diantaranya penyediaan Lab. yang memadai (Micro Teaching), serta Kegiatan Praktik Pembelajaran Micro (PPL I) dan PPL II juga telah dilaksanakan. Namun dalam pelaksanaanya sampai saat ini belum pernah diketahui bagaimana Tingkat Kesiapan Mengajar Mahasiswa Pendidikan Akuntansi setelah menempuh Proses pendidikan dari Kegiatan Perkuliahan teori sampai pada kegiatan PPL II.Hal ini menyebabkan tidak diketahuinya keberhasilan program pembelajaran serta pelaksanaan Kurikulum di Prodi Pendidikan Akuntansi yang terkait dengan penyiapan kompetensi Mengajar Mahasiswa. Oleh sebab itu peneliti tertarik untuk meneliti tentang Tingkat Kesiapan Mengajar Mahasiswa Prodi. Pendidikan Akuntansi yang telah menyelesaikan Mata Kuliah teori Kependidikan Serta telah melaksanakan Kegiatan Micro Teachig (PPL I) dan PPL II.

\section{Rumusan Masalah}

Dari Latar belakang masalah yang telah diuraikan diatas, dapat dirumuskan permasalahan

“Bagaimana Tingkat Kesiapan Mengajar Mahasiswa Prodi. Pendidikan Akuntansi FISE - UNY"?

\section{KAJIAN PUSTAKA}




\section{a. Kompetensi Menjadi Guru}

Untuk menjadi guru, seseorang haus benar-benar menyiapkan diri baik dari segi moral, sikap, pengetahuan maupun penampilannya.Profesi guru bukan merupakan suatu pekerjaan yang mudah.Oleh karena itu diperlukan kesiapan yang mantap demi keprofesionalannya sebagai guru.

Menurut Agus F. Tamyong yang dikutip oleh Uzer Usman (2005:15) yang dimaksud dengan guru profesional adalah "Orang yang terdidik dan terlatih dengan biak, sehingga memiliki pengalaman yang kaya dibidangnya". Sebagai komponen penting dari proses belajar mengajar guru harus mempunyai kualitas, cara atau metode mengajar, penguasaan dan pengelolaan materi, penampilan, kepribadian.

Menurut Sardiman, secara garis besar ada tingkatan kualifikasi profesional guru sebagai tenaga profesional kependidikan, yaitu:

1) Tingkatan capable personal, maksudnya guru diharapkan memliki pengetahuan, kecakapan, kesiapan serta sikap yang lebih mantap dan memadai sehingga mampu mengelola proses belajar mengajar secara efektif.

2) Guru sebagai inovator, yakni sebagai tenaga kependidikan yang memiliki pengetahuan, kecakapan, dan kesiapan serta sikap yang tepat terhadap pembaharuan dan sekaligus merupakan penyebar ide pembaharuan yang efektif.

3) Guru sebagai developer, yakni guru harus memiliki visi keguruan yang mantap dan luas prospektifnya. Guru harus mampu dan mau melihat jauh ke depan dalam menjawab tantangan yang dihadapi oleh sektor pendidikan sebagai suatu sistem $(2003: 135-136)$.

Sedangkan dalam Undang-Undang RI No. 14 Th 2005 tentang Guru dan Dosen, pasal 20 dijelaskan bahwa dalam melaksanakan tugas keprofesionalannya, guru berkewajiban :

1) Merencanakan pembelajaran, melaksanakan pembelajaran yang bermutu, serta menilai dan mengevaluasi hasil pembelajaran.

2) Meningkatkan dan mengembangkan kualitas dan akademik dan kompetensi secara berkelanjutan sejalan dengan perkembangan ilmu pengetahuan dan sains.

3) Bertindak objektif dan tidak diskriminatif atas dasar pertimbangan jenis kelamin, agama, suku, ras, dan kondisi fisik tertentu, atau latar belakang keluarga dan status sosial ekonomi peserta didik dalam pembelajaran.

4) Menjunjung tinggi peraturan perundang-undangan, hukum dan kode etik guru serta nilai agama dan etika.

5) Memelihara dan memupuk rasa persaudaraan dan kesatuan bangsa. (UU Guru dan Dosen, 2006:14)

Selain itu sebagai guru wajib memiliki kualitas akademik, kompetensi sertifikasi pendidik, sehat jasmani dan rohani serta memiliki tujuan pendidikan maksimal. Hal ini dilakuan sebagai upaya mempersiapkan calon pendidik yang berkualitas. Kualitas akademik diperoleh melalui pendidikan tinggi, program sarjana atau diploma empat. Dalam Undang-Undang RI No. 14 Th 2005 tentang Guru dan Dosen dijelaskan ada empat kompetensi yang harus dimiliki guru yaitu:

1) Kompetensi pedagogik, adalah kemampuan mengelola pembelajaran peserta didik 
2) Kompetensi kepribadian, adalah kemampuan kepribadian yang mantap, berakhlak mulia, arif, dan berwibawa serta menjadi teladan peserta didik.

3) Kompetensi profesional, adalah kemampuan penguasaan materi pembelajaran secara luas dan mendalam.

4) Kompetensi sosial, adalah kemampuan guru untuk berkomunikasi dan berinteraksi secara efektif dan efisien dengan peserta didik, sesama guru, orang tua atau wali peserta didik dan masyarakat sekitar. (UU Guru dan Dosen, 2006:56).

b. Kesiapan Mengajar

Kesiapan berasal dari kata "siap" yang berarti "sudah disediakan (tinggal memakai atau menggunakannya saja)" (KBBI, 2005:1059).Jadi kesiapan adalah kondisi atau keadaan sudah siap. Sedangkan menurut Kamus Psikologi, "Kesiapan (readiness) adalah tingkat perkembangan dari kematangan atau kedewasaan yang menguntungkan untuk mempraktikkan sesuatu" (Chaplin J. P, 2002:418). Pengertian lain kesiapan adalah yang dikemukakan Slameto, "Kesiapan adalah keseluruhan kondisi seseorang yang membuatnya siap untuk memberi respons/jawaban di dalam cara tertentu terhadap suatu situasi" (2003:113). Hal ini berarti kesiapan menunjuk pada pengetahuan dan pengalaman serta kesiapan yang dimiliki seseorang dalam kaitannya dengan tujuan yang dicapai.

Dalam kesiapan terdapat prinsip-prinsip dan juga aspek-aspek kesiapan, ada empat prinsip, yaitu:

1) Semua aspek perkembangan berinteraksi (saling pengaruh mempengaruhi)

2) Kematangan jasmani dan rohani adalah perlu untuk memperoleh manfaat dari pengalaman

3) Pengalaman-pengalaman mempunyai pengaruh positif terhadap kesiapan

4) Kesiapan dasar untuk kegiatan tertentu terbentuk dalam periode tertentu selama masa pembentukan dalam masa perkembangan. (Slameto, 2003:115)

Mahasiswa telah mencapai kematangan usia yaitu telah berumur 19 tahun ke atas. Hal ini berarti mahasiswa sebenarnya sudah siap bekerja karena salah satu tugas perkembangan pada saat remaja adalah menyiapkan diri untuk masuk ke dunia kerja.Selain kematangan tersebut pengalaman juga mempengaruhi kesiapan kerja. Semakin banyak pengalaman kerja yang dimiliki seseorang tersebut akan lebih siap bekerja.

Pendapat Sukirin sebagaimana dikutip oleh Iswaluyani mengatakan bahwa:

Kesiapan terhadap sesuatu akan terbentuk jika telah mencapai perpaduan antara tingkat kemasakan, pengalaman yang diperlukan serta keadaan mental dan emosi yang serasi. Dari pernyataan ini kesiapan terhadap sesuatu dipengaruhi oleh tiga hal, yaitu :

1) Tingkat kemasakan

Menunjuk pada proses perkembangan atau perrtumbuhan yang sempurna dalam arti siap digunakan. Kesiapan dibedakan menjadi kesiapan fisik dan mental yang berhubungan dengan aspek kejiwaan.

2) Pengalaman sebelumnya

Merupakan pengalaman tertentu yang diperoleh yang mempunyai kaitan dengan lingkungan, kesempatan yang tersedia, pengaruh dari luar yang tidak disengaja.Pengalaman merupakan salah satu faktor yang dapat mempengaruhi perkembangan kesiapan seseorang.

3) Keadaan mental dan emosi yang serasi 
Seseorang yang memiliki keadaan mental dan emosi yang serasi, bila keadaan mental emosi orang tersebut sejalan. Sehingga tercapai keadaan yang serasi. Keadaan ini meliputi keadaan yang kritis, memiliki pertimbangan-pertimbangan yang logis dan obyektif, bersikap dewasa dan emosi yang terendah $(2005: 11)$

Kesiapan dalam Mengajar di wujudkan dari pemahaman Kesiapan dasar mengajar yang merupakan faktor yang menentukan dalam keberhasilan mengajar. Kesiapan ini harus dimiliki dan dikuasai oleh calon guru. Kesiapan dasar mengajar meliputi :

1. Kesiapan Membuka dan Menutup Pelajarani kegiatan inti pembelajaran.

Kegiatan membuka pelajaran adalah kegiatan yang dilakukan guru untuk menciptakan suasana pembelajaran yang memungkinkan siswa siap secara mental untuk mengikuti kegiatan pembelajaran.

Kegiatan menutup pelajaran adalah kegiatan yang dilakukan guru untuk mengakhir

2. Kesiapan Menjelaskan

Menjelaskan adalah memberikan informasi yang diorganisasi secara sistematis kepada siswa.

3. Kesiapan Memberi Penguatan

Penguatan adalah tanggapan guru terhadap perilaku siswa yang memungkinkan dapat membesarkan hati siswa agar lebih terpacu dalam interaksi belajar-mengajar.

4. Kesiapan Menggunakan Media dan Alat Pembelajaran.

Media dan alat pembelajaran yang dipergunakan dalam proses pembelajaran agar siswa memperoleh kemudahan dalam memahami materi pembelajaran.

5. Kesiapan Menyusun Skenario /embelajaran.

Langkah-langkah kegiatan pembelajaran yang akan ditempuh oleh guru dan siswa dalam rangka membelajarkan siswa yang meliputi pengetahuan, keSiapan dan sikap.

6. Kesiapan Mengadakan Variasi

Variasi dalam kegiatan pembelajaran adalah perubahan yang dilakukan guru dalam kegiatan pembelajaran yang meliputi gaya belajar, pengunaan media pembelajaran, pola interaksi dan stimulasi.

7. Kesiapan Membimbing Diskusi.

Diskusi adalah sustu proses interaksi verbal secara teratur yang melibatkan sekelompok orang dalam interaksi tatap muka yang informal dengan tujuan berbagi pengalaman atau informasi, mengkonstruk konsep, mengambil suatu keputusan atau memecahkan masalah.

8. Kesiapan Mengelola Kelas.

Mengelola kelas adalah menciptakan dan memelihara kondisi belajar yang optimal bagi siswa dan mengembalikan ke kondisi belajar yg optimal apabila terdapat gangguan dalam proses pembelajaran.

9. Kesiapan Bertanya.

Bagaimana guru menyampaikan pertanyaan kepada siswa dalam Proses Pembelajaran, baik pertanyaan dasar maupun pertanyaan lanjut.

10. Kesiapan Mengevaluasi

Evaluasi adalah proses sistimatis untuk mengetahui efektivitas dan efisiensi suatu kegiatan pembelajaran ( Panduan Pembelajaran Micro UNY : 9 - 17)

\section{Pertanyaan Penelitian}

1.Bagaimana Kesiapan MengajarMahasiswa Program Studi Pendidikan Akuntansi FISE UNY dari segi Membuka dan Mnutup Pelajaran ?

2. Bagaimana Kesiapan MengajarMahasiswa Program Studi Pendidikan Akuntansi FISE UNY dari segi Penguasaan dan Penyampaian Materi ? 
3. Bagaimana Kesiapan MengajarMahasiswa Program Studi Pendidikan Akuntansi FISE UNY dari segi Melakukan Interaksi dan Skenario Pembelajaran?

4. Bagaimana Kesiapan MengajarMahasiswa Program Studi Pendidikan Akuntansi FISE UNY dari segi Penguasaan Bahasa, Penampilan dan Alokasi Waktu?

5. Bagaimana Kesiapan MengajarMahasiswa Program Studi Pendidikan Akuntansi FISE UNY dari segi Melakukan Evaluasi?

\section{CARA PENELITIAN}

Penelitian ini menggunakan pendekatan ex post facto, karena peneitian ini hanya mengungkapkan fakta saja yang telah terjadi tanpa ada manipulasi variabel atau menciptakan kondisi tertentu.

Dilihat dari sifatnya penelitian termasuk penelitian diskriptif kuantitatif, karena penelitiann ini bertujuan mengambarkan suatu keadaan yang ada dengan menggunakan data-data yang berupa angka-angka serta penafsirannya berdasarkan parameter yang berlaku.

Subjek Penelitian ini adalah Mahasiswa Prodi.Pendidikan Akuntansi yang mengambil PPL I dan PPL II tahun 2011 sejumlah 75 mahasiswa.Setelah dilakukan pengambilan data, data yang dapat diperoleh sebanyak 69 mahasiswa.

Untuk memberikah arah yang jelas serta kajian yang lebih mendalam terhadap masalah yang akan dipecahkan, maka perlu diberikan definisi operasional variabel yang ada dalam penelitian ini. Variabel dalam penelitian ini adalahPenguasaan KeSiapan dasar mengajar untuk menjadi Guru yang meliputi : Kemampuan membuka dan menutup pelajaran, menjelaskan, memberikan penguatan, menggunakan media, menyusun skenario pembelajaran, membimbing diskusi, mengelola kelas, bertanya, mengevaluasi

Metode pengumpulan data dengan menggunakan Kuesioner, metode ini mengunakan daftar pertanyaan yang telah disusun dan disiapkan sedemikian rupa sehingga responden tinggal mengisi atau menandai dengan mudah dan cepat, Kuesioner yang digunakan dalam evaluasi ini adalah closed ended questioner atau kuesioner tertutup yaitu berbagai pertanyaan yang dibuat dengan memberikan alternatif jawaban yang telah tersedia, sehingga responden tinggal memilih jawaban yang ada sesuai kondisi yang sebenarnya. Metode ini digunakan untuk mengetahui berbagai kompentensi calon guru yang telah dimiliki oleh mahasiswa

Sebelum Instrumen digunakan dilakukan Perhitungan uji validitas dan Reliabilitas, berdasarkan hasil analisis akan diketahui layak atau tudaknya kuesioner yang akan digunakan.

Data yang diperoleh akan di analisis dengan pendekatan diskriptif, analisis ini digunakan untuk memgambarkan Tingkat Kesiapan Mengajar Mahasiswa Prodi. Pendidikan Akuntansi cara mengambarkan dalam tabel kecenderungan dengan strandar yang telah ditentukan sebagai berikut

Tabel 1. Kategori Kecenderungan Kesiapan

\begin{tabular}{rl|c|}
\hline No & \multicolumn{1}{|c|}{ Formula } & Kategori \\
\hline 1 & $\mathrm{X}>\left(\mathrm{M}_{\mathrm{i}}+1 . \mathrm{SD}_{\mathrm{i}}\right)$ & Sangat Siap \\
\hline 2 & $\left(\mathrm{M}_{\mathrm{i}}+1 . \mathrm{SD}_{\mathrm{i}}\right) \geq \mathrm{X} \geq \mathrm{M}_{\mathrm{i}}$ & Siap \\
\hline 3 & $\mathrm{M}_{\mathrm{i}}>\mathrm{X} \geq\left(\mathrm{M}_{\mathrm{i}}-1 . \mathrm{SD}_{\mathrm{i}}\right)$ & Cukup Siap \\
\hline 4 & $\mathrm{X}<\left(\mathrm{M}_{\mathrm{i}}-1 . \mathrm{SD}_{\mathrm{i}}\right)$ & Kurang Siap \\
\hline
\end{tabular}




\section{HASIL PENELITIAN DAN PEMBAHASAN}

1. Kesiapan membuka dan menutup Pelajaran

Berdasarkan hasil pengolahan instrument penelitian dan mengacu pada kategorisasi yang telah ditentukan, maka dapat disusun kategori Kesiapanmembuka dan menutup Pelajaran.

Tabel 1. Hasil Kategori Kesiapan membuka dan menutup Pelajaran.

\begin{tabular}{|c|c|c|c|}
\hline \multirow{2}{*}{ No } & \multicolumn{2}{|c|}{ Frekuensi } & \multirow{2}{*}{ Kategori } \\
\cline { 2 - 3 } & Absolut & Relatif $\%$ & \\
\hline 1 & 10 & 14 & Sangat Siap \\
\hline 2 & 16 & 23 & Siap \\
\hline 3 & 28 & 41 & Cukup Siap \\
\hline 4 & 15 & 22 & Kurang Siap \\
\hline
\end{tabular}

Dari Tabel 1 di atas menunjukkan kategori Kesiapan membuka dan menutup Pelajaran.mahasiswa Program Studi Pendidikan Akuntansi FISE UNY adalah ; Sangat Siap14\%; Siap23\%; CukupSiap41\%; dan Kurang Siap22\%, sehingga dapat diketahuiPenguasaan Kesiapan membuka dan menutup Pelajaran.mahasiswa Program Studi Pendidikan Akuntansi adahah Cukup Siap.

2. Kesiapan Penguasaan dan Penyampaian Materi

Mengacu pada kategorisasi yang telah ditentukan, maka dapat disusun kategori Penguasaan Kesiapan Peanguasaan dan Penyampaian Materi

Tabel 2. Hasil Kategori Kesiapan Penguasaan dan Penyampaian Materi

\begin{tabular}{|c|c|c|c|}
\hline \multirow{2}{*}{ No } & \multicolumn{2}{|c|}{ Frekuensi } & \multirow{2}{*}{ Kategori } \\
\cline { 2 - 3 } & Absolut & Relatif $\%$ & \\
\hline 1 & 16 & 23 & Sangat Siap \\
\hline 2 & 24 & 36 & Siap \\
\hline 3 & 21 & 30 & Cukup Siap \\
\hline 4 & 8 & 11 & Kurang Siap \\
\hline
\end{tabular}

Dari Tabel 2 di atas menunjukkan kategori Kesiapan Penguasaan dan Penyampaian Materi mahasiswa Program Studi Pendidikan Akuntansi FISE UNY adalah ; Sangat Siap23\%; Siap36\%; Cukup Siap30\%; dan Kurang Siap11\%, sehingga dapat diketahui Kesiapan Peanguasaan dan Penyampaian Materi mahasiswa Program Studi Pendidikan Akuntansi adahah Siap.

3. Kesiapan Melakukan Interaksi dan Skenario Pembelajaran.

Mengacu pada kategorisasi yang telah ditentukan, maka dapat disusun kategori Penguasaan Kesiapan Melakukan Interaksi dan Skenario Pembelajaran.

Tabel 3. Hasil Kategori Kesiapan Melakukan Interaksi dan Skenario Pembelajaran.

\begin{tabular}{|c|c|c|c|}
\hline \multirow{2}{*}{ No } & \multicolumn{2}{|c|}{ Frekuensi } & \multirow{2}{*}{ Kategori } \\
\cline { 2 - 3 } & Absolut & Relatif $\%$ & \\
\hline 1 & 9 & 13 & Sangat Siap \\
\hline 2 & 11 & 14 & Siap \\
\hline 3 & 25 & 37 & Cukup Siap \\
\hline
\end{tabular}




\begin{tabular}{|l|l|l|l|}
4 & 24 & 36 & Kurang Siap \\
\hline
\end{tabular}

Dari Tabel 3 di atas menunjukkan kategori Kesiapan Melakukan Interaksi dan Skenario Pembelajaran. Mahasiswa Program Studi Pendidikan Akuntansi FISE UNY adalah ; Sangat Siap 13\%; Siap 14\%; Cukup Siap 37\%; dan Kurang Siap 36\%, sehingga dapat kita ketahui Penguasaan Kesiapan Melakukan Interaksi dan Skenario Pembelajaran mahasiswa Program Studi Pendidikan Akuntansi adalah Cukup Siap.

4. Kesiapan Penggunaan Bahasa, Penampilan Gerak dan Alokasi Waktu.

Mengacu pada kategorisasi yang telah ditentukan, maka dapat disusun kategori Penguasaan Kesiapan Penggunaan Bahasa, Penampilan Gerak dan Alokasi Waktu.

Tabel 4. Hasil Kategori Kesiapan Penggunaan Bahasa, Penampilan Gerak dan Alokasi Waktu.

\begin{tabular}{|c|c|c|c|}
\hline \multirow{2}{*}{ No } & \multicolumn{2}{|c|}{ Frekuensi } & \multirow{2}{*}{ Kategori } \\
\cline { 2 - 3 } & Absolut & Relatif $\%$ & \\
\hline 1 & 17 & 25 & Sangat Siap \\
\hline 2 & 22 & 32 & Siap \\
\hline 3 & 26 & 38 & Cukup Siap \\
\hline 4 & 4 & 5 & Kurang Siap \\
\hline
\end{tabular}

Dari Tabel 4 di atas menunjukkan kategori Kesiapan Penggunaan Bahasa, Penampilan Gerak dan Alokasi Waktu mahasiswa Program Studi Pendidikan Akuntansi FISE UNY adalah ; Sangat Siap 25\%; Siap32\%; Cukup Siap38\%; dan Kurang Siap5\%, sehingga dapat diketahui Penguasaan Kesiapan Penggunaan Bahasa, Penampilan Gerak dan Alokasi Waktu. mahasiswa Program Studi Pendidikan Akuntansi adahah Cukup Siap.

5. Kesiapan Melakukan Evaluasi

Mengacu pada kategorisasi yang telah ditentukan, maka dapat disusun kategori

Penguasaan Kesiapan Melakukan Evaluasi

Tabel 5. Hasil Kategori Kesiapan Melakukan Evaluasi

\begin{tabular}{|c|c|c|c|}
\hline \multirow{2}{*}{ No } & \multicolumn{2}{|c|}{ Frekuensi } & \multirow{2}{*}{ Kategori } \\
\cline { 2 - 3 } & Absolut & Relatif $\%$ & \\
\hline 1 & 14 & 20 & Sangat Siap \\
\hline 2 & 22 & 32 & Siap \\
\hline 3 & 26 & 38 & Cukup Siap \\
\hline 4 & 7 & 10 & Kurang Siap \\
\hline
\end{tabular}

Dari Tabel 5 di atas menunjukkan kategori Kesiapan Melakukan Evaluasi mahasiswa Program Studi Pendidikan Akuntansi FISE UNY adalah ; Sangat Siap20\%; Siap32\%; Cukup Siap38\%; dan Kurang Siap10\%, sehingga dapat kita ketahuiKesiapanMelakukan Evaluasi mahasiswa Program Studi Pendidikan Akuntansi adalah Cukup Siap.

Hasil penelitian ini menunjukkan bahwa Penguasaan Kesiapan Mengajar mahasiswa Program Studi Pendidikan Akuntansi dari segi Kesiapan membuka dan menutup Pelajaran adalah Cukup Siap. Kesimpulan ini didasarkan pada hasil analisis kecenderungan data yang menunjukkan : sangat Siap 14\%; Siap 23\%;Cukup Siap 41\%; dan Kurang Siap 22\%. Hasil penelitian ini sesuai dengan kajian teori yang telah dipaparkan sebelumnya, yaitu bahwa kesiapan membuka Pelajaran yang 
dimiliki oleh Mahasiswa akan menyebabkan seseorang tersebut akan lebih berhasil dalam mengajar, Hal ini karena bila mahasiswa memiliki kesiapan membuka dan menutup Pelajaran yang tinggi akan menimbulkan motivasi dan kemauan, serta ketertarikan dalam belajar pada siswa. Kemauan dan rasa ketertarikan untuk belajar yang besar serta ini lah yang akan menciptakan suasanan pembelajaran yangn menyenangkan yang berimbas pada keberhasilan dalam kegiatan pembelajaran.

Kesiapan Mengajar mahasiswa Program Studi Pendidikan Akuntansi dari segi Penguasaan dan Penyampaian Materi adalah Siap. Kesimpulan ini didasarkan pada hasil analisis kecenderungan data yang menunjukkan :sangat Siap 23\%; Siap 36\%; Cukup 30\%; dan Kurang 11\%. Hasil penelitian ini sesuai dengan kajian teori yang telah dipaparkan sebelumnya, yaitu bahwa penguasaan dan Penyampaian materi yang dimiliki oleh Mahasiswaakan menyebabkan seseorang tersebut akan lebih berhasil dalam mengajar. Hal ini karena bila mahasiswa memiliki Penguasaan dan Penyampaian yang Siap akan menimbulkan kejelasan dalam penyampaian materi dalambelajar pada siswa, yang akan menimbulkan peningkatkan daya serap keilmuan serta kompetensi yang dimiliki oleh peserta didik. Daya serap keilmuan dan kompetensi ini yang akan dijadikan sebagai parameter keberhasilan dalam kegiatan pembelajaran.

Kesiapan Mengajar mahasiswa Program Studi Pendidikan Akuntansi dari segi Interaksi dan Skenario Pembelajaran adalah Cukup Siap. Kesimpulan ini didasarkan pada hasil analisis kecenderungan data yang menunjukkan :Sangat siap 13\%; Siap 14\%; Cukup 37\%; dan Kurang 36\%. Hasil penelitian ini sesuai dengan kajian teori yang telah dipaparkan sebelumnya, yaitu bahwa Interaksi dan Skenario Pembelajaran yang dilaksanakan oleh Mahasiswa akan menyebabkan mahasiswa tersebukt memiliki kesiapan dalam merencanakan serta mengelola kegiatan pembelajaran serta menjalin hubungan yang hangat dengan peserta didik. Interaksi dengan pserta didik yang Siap akan menimbulkan suasana belajar yang menyenangkan karena pembelajaran akan berlangsung dua arah, dimana peserta didik akan senantian aktif dalam setiap kegiatan pembelajaran karena adanya interaksi yang Siap dari Pengajar. Sedangkan skenario yang Siap akan dapat menimbulkan pembelajaran terarah sesuai dengan Kompetensi yang diharapkan.

Kesiapan Mengajar mahasiswa Program Studi Pendidikan Akuntansi dari segi Penggunaan Bahasa, Penampilan Gerak dan Alokasi Waktu adalah Cukup Siap. Kesimpulan ini didasarkan pada hasil analisis kecenderungan data yang menunjukkan :Sangat Siap 25\%; Siap 32\%; Cukup 38\%; dan Kurang 5\%. Hasil penelitian ini sesuai dengan kajian teori yang telah dipaparkan sebelumnya, yaitu bahwa Penggunaan Bahasa, Penampilan Gerak dan Alokasi Waktu yang dimiliki oleh Mahasiswa akan menyebabkan seseorang tersebut akan lebih berhasil dalam mengajar. Hal ini dikarenakan Pemilihan bahasa yang sesuai dengan pemahaman peserta didik akan menghilangkan keraguan pemahaman yang dimiliki peserta didik. Penampilan seorang guru yang Siap atau meyakinkan dan percaya diri akanmendorong keseriusan peserta didik dalam mengikuti pembelajaran. Pengalokasian waktu yang memadai dan Siap akan memberikan rasa nyaman bagi peserta didik untuk mengikuti dan memahami setiap kompetensi yang diajarkan. Apabila Penggunaan Bahasa, Penampilan Gerak dan Alokasi Waktu yang Siap dikuasai oleh Pengajar maka dimungkinkan kegiatan Pembelajaran akan berjalan dengan Siap pula.

Kesiapan Mengajar mahasiswa Program Studi Pendidikan Akuntansi dari segi Melakukan Evaluasi adalah Cukup Siap. Kesimpulan ini didasarkan pada hasil analisis kecenderungan data yang menunjukkan :Sangat Siap 20\%; Siap 32\%; Cukup 
Siap 38\%; dan Kurang Siap 10\%. Hasil penelitian ini sesuai dengan kajian teori yang telah dipaparkan sebelumnya, yaitu Kesiapan melakukan Evaluasi dapat mengetahui ketercapaian kegiatan yang dilakukan. Selain itu dengan kesiapan melakukan Evaluasi maka Hasil Pembelajaran akan memiliki nilai Keadalan data yang dapat dipercaya. Dengan kata lain Siap melakukan Evaluasi maka data yang diperoleh dalam kegiatan pembelajaran (nilai peserta didik) akan lebih dapat dipertanggung jawabkan.

\section{KESIMPULAN}

Dari Hasil penelitian serta pembahasan dapat diambil Kesimpulan sebagai berikut :

1. Kesiapan MengajarMahasiswa Program Studi Pendidikan AkuntansiFISE UNY dari segi membuka dan menutup Pelajaran adalah Cukup Siap.

2. Kesiapan MengajarMahasiswa Program Studi Pendidikan AkuntansiFISE UNY dari segi Penguasaan dan Penyampaian Materi adalah Siap.

3. Kesiapan MengajarMahasiswa Program Studi Pendidikan Akuntansi FISE UNY dari segi Melakukan Interaksi dan Skenario Pembelajaran adalah Cukup Siap.

4. Kesiapan MengajarMahasiswa Program Studi Pendidikan Akuntansi FISE UNY dari segi Penguasaan Bahasa, Penampilan dan Alokasi Waktu adalah Cukup Siap.

5. Kesiapan MengajarMahasiswa Program Studi Pendidikan Akuntansi FISE UNY dari segi Melakukan Evaluasiadalah Cukup Siap.

\section{Daftar Pustaka}

Chabib Thoha. (1996). Teknik evaluasi pendidikan. Jakarta: Raja Grafindo Persada.

Fernandes, H. J. X. (1984) Evaluation of educational program. Jakarta. National Educational Planning.Evaluation and curriculum Development.

Nana Sudjana 919950. Teknik pengukuran dan evaluasi Pendidikan.Bandung. Sinar Baru

Oemar Hamalik. (1993). Tekhnik pengukuran dan evaluasi pendidikan. Bandung: CV. Madar Maju.

Oriondo, Leonora. L.dkk. (1984). Evaluating Educational Outcomes, Manila: Rex Printing Company, Inc.

Sardiman AM.(2010). Interaksi dan Motivasi belajar Mengajar. Jakarta. PT. Raja Grafindo

Setyo Utomo (1987). Teknologi Pendidikan Kejuruan. Yogyakarta. Thesis

Sunaryo (1983). Evaluasi Hasil Belajar. Yogyakarta. LP3EF

Sudjana,N \& Ibrahim. (2001).Penelitian belajar mengajar.Bandung : Sinar Biru.

Tim Penyusun (2010).Panduan Praktik Pembelajaran Micro. UPPL UNY 
Worthen, Blaine. R. \& Sanders, James. R. (1973).Educational Evaluation: a system theory and practice. California: Charles A Jones Publishing Company. 